\title{
Development of Tourism Master Plan in Panji Anom Village, Sukasada District, Buleleng Regency
}

\author{
Wahjoedi Wahjoedi ${ }^{1, *}$ I Putu Panca Adi ${ }^{1}$ Damiati Damiati ${ }^{2}$ \\ ${ }^{I}$ Physical Education Health and Recreation Study Program, Universitas Pendidikan Ganesha, Singaraja, Indonesia \\ ${ }^{2}$ Culinary Arts Vocational Education Study Program, Universitas Pendidikan Ganesha, Singaraja, Indonesia \\ *Corresponding author.Email: wahjoedi@undiksha.ac.id
}

\begin{abstract}
This development research aims to produce a master plan for tourism development in Panji Anom Village, Sukasada, Buleleng, Bali. The determination of Panji Anom Village as the research location was due to 1) well as the lack of support from the Panji Anom Village Government and other tourism stakeholders. ,2) Panji Anom Village has been established as a unit of watershed area (DAS) which is the locus for the development of cooperation with Undiksha, and 3) On a micro scale in the previous year, research and PkM activities have been carried out in Panji Anom Village but have not touched the level umbrella program and master plan for pioneering and developing tourism in an integrated and complete manner. This research produces First, the main tourism potential map of Panji Anom Village is 1) Nature tourism, especially "Panorama Puncak Landep", 2) Trekking, 3) Camping, 4) Agriculture, and 5) Honey bee cultivation, 6) Religious tourism, and 7) Pilot breeding of rare animals in forest areas managed by LPHD. Second, maps of 5 trekking routes that are worthy of sale for tourists with their own characteristics and uniqueness, namely: 2 maps short trips, 2 maps of medium routes medium trips, and 1 long trip.
\end{abstract}

Keywords: Master Plan, Tourism Development.

\section{INTRODUCTION}

The Law of the Republic of Indonesia (UU RI) No. 22 of 1999 concerning Regional Government mandates that development will be more focused in rural areas, so that social changes will occur where urban people feel happy to go to the village for recreation [1]. Meanwhile, RI Law No. 10 of 2009 concerning Tourism states that tourism is an integral part of national development which is carried out in a systematic, planned, integrated, sustainable, and responsible manner while still providing protection for religious values, culture that lives in society, sustainability and environmental quality and national interest [2]. Thus, the village is a tourism development target that deserves the attention of various stakeholders, including the development of integrated tourism based on environmental conservation and local wisdom in Panji Anom Village, Sukasada District, Buleleng Regency.

Panji Anom Village is one of the villages projected as a pilot village for tourism development with the main tourism potential in the form of terraced land topography or dry terraces, hills and valleys with protected forest vegetation and productive plantation forests (cloves, cocoa, durian and rambutan), fields/gardens. , and productive land with river flow and subak management with fairly swift water flow, the focus of beautiful scenery, both in the form of hills, valleys, forests, rivers, and the vast expanse of blue sea to the north.

Of the various basic potentials and advantages, currently what is being developed as a pioneering tourist attraction is trekking. Then since May 2019 the opening of a new access road which was built independently together with the Indonesian Army has been initiated, which connects various areas that have the potential to be developed into tourist attractions. Supporting tourism potential that is in harmony with the topographic contours of the hills with a combination of hills, valleys, forests and various tree vegetation coveted by tourism managers is nature tourism and various adventure tours supported by culinary tourism. Responding to these matters along with the results of initial visits/observations that have been carried out several times since November 2020, there is a fundamental weakness, namely that the tourism manager in Panji Anom Village does not yet have adequate knowledge and skills about pioneering tourism development based 
on environmental conservation and local wisdom. local wisdom), and the unavailability of a tourism development master plan in Panji Anom Village. If this happens for a long period of time, it will certainly result in the stagnation of tourism development plans in Panji Anom Village as a whole.

Based on these potentials and problems, it is considered very important and urgent to conduct research as an acceleration of the tourism development program in Panji Anom Village, Sukasada District, Buleleng Regency, Bali Province.

It is important that the tourism development master plan is prepared by the tourism manager in Panji Anom Village so that it grows into a model and pilot project which is expected to be able to synergize and cooperate more productively with tourism stakeholders inside and outside the Panji Anom Village environment. In other words, the master plan for tourism development will further strengthen the character of natural tourism which is supported by more varied tourist vehicles so that between one tourist vehicle and another tourist vehicle will complement each other and increase the attractiveness of tourism in Panji Anom Village. In the end, the uniqueness of each tourist vehicle accompanied by the disparity of the tourist rides can spur more integrated tourism services and have the potential to be developed into a very attractive tourist safari and bring a multiplier effect for improving the welfare of the people of Panji Anom Village, as well as environmental conservation and local wisdom. .

Based on the potential, facts, problems, the results of consultations with Perbekel Panji Anom, Head of BPD, Bumdes and Pokdarwis of Panji Anom Village, it is considered important and urgent to conduct research: "Preparing a Master Plan for Tourism Development in Panji Anom Village, Sukasada District, Buleleng" so that it is not only able to bring in profits but is also able to increase the diversification of services or tourism vehicles in Panji Anom Village in particular, and Buleleng Regency in general..

\section{THEORETICAL REVIEW}

\subsection{Tourism}

Talking about tourism, there are several terms related to the word tourism, including: tourism, tourism, tourists, tourist objects, tourism, and so on. The word tourism comes from ancient Java which has now enriched the Indonesian language repertoire [3]. According to the Big Indonesian Dictionary [4], tourism is a verb which means: (a) traveling together, (b) picnic. Pari means: all, all, then Tourism can be interpreted as everything related to traveling together. Tourist means a person who undertakes a tour, or a person who travels. A tourist attraction concerns a place, location, or everything that is an attraction to be visited, studied or seen by tourists. While everything related to tourism is called tourism.

In order to obtain the same frame of reference and understanding, it is more appropriate to refer to the Law of the Republic of Indonesia No. 10 of 2009 concerning Tourism. Some of the more complete terms related to tourism are cited here [2].

Tourism is a travel activity or part of the activity that is carried out voluntarily and temporarily to enjoy tourist objects and attractions. Tourists are people who carry out tourism activities. Tourism is everything related to tourism, including the exploitation of tourist objects and attractions as well as businesses related to these fields. Tourism is everything related to the implementation of tourism. Tourism business is an activity aimed at providing tourism services, providing or operating tourist objects and attractions, tourism facilities business and other related businesses in that field. Tourist objects and attractions are everything that is the target of tourism. Tourism area is an area with a certain area that is built or provided to meet tourism needs.

Based on this explanation, what is meant by tourism in this study is a trip that is carried out temporarily from one place to another that has tourist objects and attractions to be enjoyed as a recreation or entertainment that gets inner and outer satisfaction. Meanwhile, what is called a tourist is a person who travels from his place of residence without settling in the place he visited, or only temporarily staying in the place he visited.

\subsection{Geographical Condition of Panji Anom Village}

Panji Anom village has an area of 975,850 ha. The entire area is used for various purposes of life, including for settlements, rice fields, plantations, cemeteries, parks, offices, and other public infrastructure. The area of residential land is 55 ha, rice fields 318 ha, plantations 304 ha, graves 1 ha, garden 0.01 ha, offices 0.04 ha, other public infrastructure area 297.8 ha (Profile Data of Panji Anom Village, 2018). Panji Anom Village is located in Sukasada District, Buleleng Regency, which is a plateau and hills with an altitude of 320 meters above sea level with a slope of $0-10 \%$.

Panji Anom Village has a subtropical climate with an average rainfall of 3,000-4,000 mm/year, from November to April Panji Anom Village experiences the rainy season and from May to October the dry season with an average minimum air temperature of $32 \mathrm{oC}(24-260 \mathrm{C})$.

Panji Anom Village has 4 Service Banjars, namely: 1) Batupulu Service Banjar, 2) Lebah Siung Service Banjar, 3) Abasan Service Banjar, and 4) Pancoran Service Banjar. Panji Anom village has territorial 
boundaries adjacent to several villages. To the north it is bordered by Pemaron Village, Buleleng District, to the south by Wanagiri Village, to the east by Panji Village, and to the west by Tegallinggah Village (all three are in Sukasada District). The total population of Panji Anom Village is 10,478 people (men: 4,754 people, women: 5,724 people) spread over 2,679 families.

\subsection{Tourism Potential of Panji Anom Village}

Potential in tourism can be interpreted as capital or assets owned by a tourist destination and empowered for economic interests which are ideally summarized in it, including attention to the protection and preservation of cultural aspects. Suarka explains that tourism potential is everything that is in an area that is developed into a tourist attraction, this potential can be divided into two, namely cultural potential, namely the potential that grows and develops in the community such as customs, livelihoods and arts, and cultural potential. natural potential, namely the potential that exists in the community in the form of natural physical and geographical potential [5]. According to Yoeti and Marpaung that tourism potential is something that can be developed into the attraction of a tourist attraction [6][7]. In this study, tourism potential is something that is owned by a tourist destination that can be developed so that it becomes the attraction of a tourist object. Tourism potential is divided into two types, namely: physical potential and non-physical potential.

Physical potential is the potential related to natural resources in the village such as land, water, agricultural land, livestock, climate weather and others. Meanwhile, non-physical potential is all potential related to village communities and their behavior. Other non-physical potentials are village institutions, village apparatus, customs and culture [8].

Law No. 10 of 2009 concerning Tourism, Chapter I article 4.6 states that tourist objects and tourist attractions are as follows [2];

1. Objects and tourist attractions created by God Almighty, in the form of natural conditions, as well as flora and fauna.

2. Human-made tourist objects and attractions in the form of museums, historical relics, agro tourism, water tourism, nature adventure tourism, recreation parks and entertainment venues.

Objects and tourist attractions are interrelated formations or activities and facilities that can attract tourists or visitors to come to a certain area or place. The government stipulates that the development of tourist objects and attractions is carried out by means of seeking, managing, and creating new objects as tourist objects and attractions by taking into account (a) the ability to encourage the improvement of the development of socio-economic and socio-cultural life; (b) Religious values, customs, and views and values that live in society; (c) Cultural preservation and environmental quality; and (d) the continuity of the tourism business itself.

Objects and tourist attractions are interrelated formations or activities and facilities, which can attract tourists or visitors to come to a certain area or place. The government stipulates that the development of tourist objects and attractions is carried out by means of seeking, managing, and creating new objects as tourism objects and attractions by taking into account: (a) the ability to encourage the improvement of the development of socio-economic and socio-cultural life; (b) Religious values, customs, and views and values that live in society; (c) Cultural preservation and environmental quality; and (d) the continuity of the tourism business itself.

Based on the results of the analysis of village profile documents and field observations, data obtained that Panji Anom Village has strived to become a pioneering object for tourism development with the main tourism potential in the form of terraced land topography or dry terraces, hills and valleys with protected forest vegetation and productive forest plantations (cloves, cocoa, durian and rambutan), fields/gardens, and productive land with river flow and subak management with a fairly swift flow of water, the focus of beautiful scenery, whether in the form of hills, valleys, forests, rivers, and the vast expanse of blue sea in the north.

Of the various basic potentials and advantages, currently what is being developed as a pioneering tourist attraction is trekking. Then since May 2019 the opening of a new access road which was built independently together with the Indonesian Army has been initiated, which connects various areas that have the potential to be developed into tourist attractions. Supporting tourism potential that is in harmony with the topographic contours of the hills with a combination of hills, valleys, forests and various tree vegetation coveted by tourism managers is nature tourism and various adventure tours supported by culinary tourism. Responding to these matters along with the results of initial visits/observations that have been carried out several times since November 2020, there is a fundamental weakness, namely that the tourism manager in Panji Anom Village does not yet have adequate knowledge and skills about pioneering tourism development based on environmental conservation and local wisdom. local wisdom) If this happens for a long time, it will result in the stagnation of tourism development plans in Panji Anom Village as a whole.

Potential in tourism can be interpreted as capital or assets owned by a tourist destination and empowered for economic interests which are ideally summarized in it, including attention to the protection and preservation of 
cultural aspects. Suarka explains that tourism potential is everything that is in an area that is developed into a tourist attraction, this potential can be divided into two, namely cultural potential, namely the potential that grows and develops in the community such as customs, livelihoods and arts, and cultural potential [5]. natural potential, namely the potential that exists in the community in the form of natural physical and geographical potential. According to Yoeti and Marpaung that tourism potential is something that can be developed into the attraction of a tourist attraction [6]. In this study, tourism potential is something that is owned by a tourist destination that can be developed so that it becomes the attraction of a tourist attraction. Tourism potential is divided into two types, namely: physical potential and non-physical potential.

Objects and tourist attractions are interrelated formations or activities and facilities, which can attract tourists or visitors to come to a certain area or place. The government stipulates that the development of tourist objects and attractions is carried out by means of undertaking, managing, and creating new objects as tourism objects and attractions by taking into account: (a) The ability to encourage the improvement of the development of socio-economic and socio-cultural life; (b) Religious values, customs, and views and values that live in society; (c) Cultural preservation and environmental quality; and (d) the sustainability of the tourism business itself.

Panji Anom village has a land topography in the form of terraced rice fields (erring terraces), hills, productive plantations, and protected forests that are still well maintained. It is true that this village has beautiful natural scenery and is still well maintained, so it is very suitable to be developed as a tourist village, especially nature tourism.

Panji Anom Village has been known to have extraordinary tourism potential. Agricultural area with terraced rice fields with tracking paths surrounded by beautiful scenery adds to the beauty of this location. From Panji Anom village, you can also see the expanse of sea that stretches on the north coast. Village communities still maintain natural wealth, especially rice fields, plantations, and water sources properly, therefore people want to have natural tourist destinations. We really hope that the wishes of the community can be realized, namely a mainstay tourism destination, said Perbekel/Village Head Panji Anom I Made Gina which was agreed by the Chairperson of the Panji Anom Village Representative Body at the Panji Anom Village Office: Thursday, February 4, 2021. In Panji Anom Village there are also waterfalls and there is potential for religious tourism. This is what drives the community to move to realize the common goal of how the village becomes a tourist village favored by tourists. Supported by the progress of road infrastructure development or access to areas that have tourism potential, as well as the arrangement of the environment, he hopes that the wishes of the residents can be realized.

Based on the initial findings from the results of several initial observations and coordination with the Panji Anom Village Perbekel and the Head of the Panji Anom BPD at the Panji Anom Village Office, day: Thursday, February 4, 2021, they hope that the government (Bali Province and Buleleng Regency) will be more willing pay attention to the pioneering tourist attraction in Panji Anom Village. In addition, both of them hope that there will be a lot of support from Undiksha in the aspect of preparing master plans and fostering / developing human resources for tourism managers in Panji Anom Village in a sustainable manner.

\section{METHODS}

This study uses a survey research design for the first year, and development for the second year, and so on. The research data obtained are document analysis techniques, Google Form-based questionnaires, in-depth observations and interviews, and field searches (on the spot and on the route) based on the Strava application and satellite imagery sensing.

\section{RESULT AND DISCUSSIONS}

\subsection{Panji Anom Village Nature Tourism}

Nature tourism, the main and prospective natural tourism destination to be developed is natural scenery which has been collectively given the name, namely: "Panorama Puncak Landep-PCL". PCL is a topographical landscape of an area located on a hill with a wide and amazing view, in the form of a stretch of sea from the west to the east end, community villages, urban housing, government or private buildings or buildings, productive plantation forests, and expanse of rice fields with very beautiful dry terraces, as well as productive forests in the west and east, and protected forests in the south which is directly adjacent to Wanagiri Village. As a center of activity, a representative shop has been established to support the needs of tourists belonging to the community who are very caring and proactively involved with the research team in the pioneering and development of nature tourism in Puncak Landep, Panji Anom Village.

\subsection{Trekking}

Trekking, proportional meaning of the PCL above, the tourism vehicle that has the potential to be developed is trekking. Trekking is an exploration activity carried out by walking along village roads, footpaths, rice fields on residential land, agricultural land/rice fields, community-owned gardens, productive plantation forests or protected forests, following the 
flow of subak waters, crossing small rivers (telabah), stop at special spots such as areas that have a supernatural aura, temples, temples, or stop at an art hall. Along with research activities that collaborate with Community Service (PkM) activities in the period from August to September 2021, a "Trekking Route" map in the PCL tourist area has been successfully created.

The determination of the trekking route was preceded by topographical analysis, quite intensive and in-depth interviews, initial observations, and the deployment of the Mapping Team using geospatial and cartographic data [9][10][11][12][13], signs/directions, legends, symbols based on satellite imagery [12] [14][15][16][17][18], enriched through the Strava application, Google Earth and the Global Positioning System/GPS [12].

Through these careful stages, finally 5 trekking routes were successfully created and worthy of being sold with their own characteristics and uniqueness (Route 1: Medium Trip, Route: 2: Short Trip, Route 3: Short Trip, Route 4: Medium Trip, and Route 5: Long Trip).

\section{CONCLUSION}

Based on the results of research carried out gradually and carefully, it was concluded that: First, the main tourism potential map of Panji Anom Village is 1) Nature tourism, especially "Panorama Puncak Landep", 2) Trekking, 3) Camping, 4) Agriculture, and 5) Honey bee cultivation, 6) religious tourism, and 7) pioneering breeding of rare animals in forest areas managed by LPHD. Second, 5 trekking routes were successfully mapped out for tourists with their own characteristics and uniqueness, namely: 2 maps of short trekking routes (short trips), 2 maps of medium routes (medium trips), and 1 long route (long trip).

\section{REFERENCES}

[1] Undang-Undang Republik Indonesia Nomor 22 Tahun 1999 tentang Pemerintahan Daerah, Jakarta: Kementerian Sekretariat Negara R.I.

[2] Undang-Undang Republik Indonesia Nomor 10 Tahun 2009 tentang Kepariwisataan, Bandung: Citra Umbara.

[3] Suwantoro, G. 2004. Dasar-dasar Pariwisata.Yogyakarta: ANDI.

[4] Depdiknas., 2005. Kamus Besar Bahasa Indonesia, edisi ketiga. Jakarta: Balai Pustaka

[5] Suarka, Fany Maharani. 2010. Strategi pengembangan Ekowisata Di Desa Jehem Kecamatan Tembuku Kabupaten Bangli. Tesis. Universitas Udayana. Denpasar

[6] Yoeti, H. Oka A., 2001. Ilmu Pariwisata: Sejarah, Perkembangan, dan Prospeknya. Jakarta: PT. Pertja.
[7] Marpaung, Happy. 2000. Pengetahuan Kepariwisataan. Bandung: Alfabeta.

[8] Kusmayadi, dan Sugiarto, Endar. Metodologi Penelitian dalam Bidang Kepariwisataan. Jakarta: PT Gramedia Pustaka Utama, 2000.

[9] Kertanegara U, Laila A, Sudarsono B. (2013). Peninjauan Secara Kartografis Dalam Pembuatan Peta Kampus Universitas Diponegoro. Jurnal Geodesi Undip Oktober 2013, Volume 2, Nomor 4, Tahun 2013, (ISSN : 2337-845X)

[10] Handoyo S. (2009). Kaidah Kartografis; Sebuah kontemplasi Profesi. Jakarta. Forum Teknik Atlas Badan Informasi Geospasial.

[11] Olson JM(2001). International Encyclopedia of the Social \& Behavioral Sciences . Diakses pada https://www.sciencedirect.com/topics/agriculturaland-biological-sciences/cartography

[12] Yudhi R, Suprayogi A, Yuwono BD. (2018). Pembuatan Peta Jalur Pendakian Gunung Lawu. Jurnal Geodesi Undip Volume 7, Nomor 4, Tahun 2018, (ISSN : 2337-845X).

[13] Campell J. (1991). Introductory Cartography. Second Edition. Wm. C. Brown Publishers, Dubuque, IA. (Excellent university-level textbook that focuses on map design and cartography.

[14] Pahlenviannur MR. (2019). Pemanfaatan Informasi Geospasial Melalui Interpretasi Citra Digital Penginderaan Jauh untuk Monitoring Perubahan Penggunaan Lahan. JPIG (Jurnal Pendidikan dan Ilmu Geografi) Vol. 4, No. 2, September 2019 Halaman: $\quad 18-26 \quad$ Online: http://ejournal.unikama.ac.id/index.php/JPIG/

[15] Suwargana N. (2013). Resolusi Spasial, Temporal Dan Spektral Pada Citra Satelit LANDSAT, SPOT dan IKONOS. Jurnal Ilmiah WIDYA Volume 1 Nomor 2 Juli-Agustus 2013.

[16] Susetyo DB, Syetiawan A, Octariady J.(2017). Perbandingan Ketelitian Geometrik Citra Satelit Resolusi Tinggi dan Foto Udara untuk Keperluan Pemetaan Rupabumi Skala Besar. Seminar Nasional Penginderaan Jauh ke-4 Tahun 2017.

[17] Martoyo E, Mustafa H, Tisnasendjaja AR, Setyawan AM. (2017). Membandingkan Ketelitian Citra Google Earth Terhadap Hasil Pengukuran Lapangan. GEOPLANART Vol 1, No 1, Mei 2017.

[18] Ramdan H. (2020). Drone For Rehabiltasi Hutan dan Lahan. Disampaikan dalam paparan Webinar Mapping Drone Dalam Upaya Mengoptimalkan Pengelolaan Hutan Pada Wilayah KPH. Indonesia Mapping Community. Diakses pada https://www.youtube.com/watch?v=BacYc9PMxm $\mathrm{s} \& \mathrm{t}=1256 \mathrm{~s}$ 